\title{
Analysis of the pedagogical components of 24 significant experiences in sports interest centers in Bogotá, Colombia
}

\author{
Pedro Galvis Leal ${ }^{1 \mathrm{a}}$, Nidia-Judith Torres $^{2}$, and Deisy Baracaldo ${ }^{3}$ \\ ${ }^{1}$ Faculty of Education, Department of Science Education, Libre University, Colombia. \\ ${ }^{2}$ Physicak Education Faculty, National Pegagogical University, Colombia. \\ ${ }^{3}$ Faculty of Education, Department of Science Education, Libre University, Colombia.
}

\begin{abstract}
The regulatory framework of Bogotá proposes an education that will combine academic excellence and holistic training, which will ensure better, well-being, opportunities, and quality of life for individuals, families, and groups [1]. One of the strategies used for this purpose was called Sports Interest Centers (SIC), an extracurricular space in which Bogotá public school students could select a sport to practice. The objective of this study is to recognize, integrate, re-order and express the pedagogical elements that compose the educational dynamics of 24 schools that used this strategy, as participants in the city's Sports Interest Centers Festival (SICF). A collaborative hermeneutical study was carried out to understand the educational dynamics and consciously develop the description, analysis, and interpretation of the component elements of a system of pedagogical and didactic actions and their relationships, through school sports. The results demonstrate different emerging pedagogical categories geared at the acquisition of essential knowledge for good living and therefore implicating methodologies that favor the body, displace the mechanical gaze of sports, and bring their transcendence and complexity to school life.
\end{abstract}

Keywords: School sport; pedagogical components; sports interest centers

\section{Introduction}

Educational research has recently generated a new focus in analyzing the non-traditional spaces of schools, especially those which do not prioritize "academic achievement", to discuss central themes in the holistic development of the students like social affectivity [2], emotional intelligence [3]; the power of citizens [4], ethnic education [5], and body consciousness [6].

\footnotetext{
${ }^{a}$ Corresponding author: pepegale@gmail.com
} 
In the same way, the education secretariat of Bogotá established, the Developmental Plan, which foresaw "a city that reduced segregation and discrimination with the human being at the center of the focus of development" [7], and with the goal of improving the educational quality in District Educational Institutions (DEIs). Consequently, the strategy Curriculum for academic excellence and holistic development in elementary and secondary education-[8], was implemented. Its primary goal is holistic training "as a lifelong process, in which the school is just one more setting for its development" in a diverse, integrative, evolving, and promising way. It offers students essential knowledge that reinforces their learning and cultivates their being through arts, sports, and civil participation, with the goal of incentivizing the development of "essential knowledge for better living" [9]. Thus, from the integrative perspective of physical education, recreation and sports are a catalyst for "being" (developing a citizen conscious of their physicality), for "living together" (developing aptitudes and attitudes for relationships with others), for "doing" (presenting challenging practices and harmonious interactions in playful environments), and for "learning" (developing higher-level thought processes through physical experiences).

With the goal of honoring the experience of the Sport Interests Centers SICs and recognizing the process carried out by teachers, children, and young adults, the DSE held an event in 2015 called the Meaningful Experiences Festival. It called the DEIs to register and participate in the event. The experiences written in the integrative area of "Physical Education, Recreation, and Sports" were selected and evaluated by experts, and later systematized by the team at the Pedagogical and Social Observatory of the Body.

\section{Method}

The systematization of pedagogical experiences [10], [11], [12], is based on Action Research [13], and therefore it is in the socio-critical investigative paradigm. It is performed through the ordering and reconstruction of lived experience and it permits the discovery and the explanation of important takeaways, with the goal of evaluating, sharing, and debating them, while contributing to the body of pedagogical knowledge through emerging "lessons learned".

\subsection{Participants}

24 teachers from different SIC of the DEIs that implemented this strategy in the city of Bogotá, registered and selected by the Sport Interest Centers Festival 2015, located in 12 districts of the city of Bogotá, and 100 students (selected at random) who were interviewed in the selected SICs.

\subsection{Equipment and data}

Three types of data collection methods were used. 1) an online sign-up form administered by the Sport Interest Centers Festival, 2) semi-structured interviews of the teachers and 3) semi-structured interviews of the students. Additionally, video recordings were taken in some Sport Interest Centers, to complement the information obtained. The narratives of the teachers and their students, for example, what was written on the registration form, was transcribed in Rich Text Format (RTF) documents to later be entered into a database or "hermeneutical unit" in the Atlas Ti system. 


\title{
2.3 Procedure
}

In accordance with Jara's proposal, the study consisted of the following steps: 1) define a plan for the Systematization of Significant Experiences from which the framework of the SICF was designed, 2) ask the initial questions: leading questions to establish the basis for systematization; 3) recover the lived process: reconstruct what happened in an orderly manner, classify the available information and identify the stages of the process; and then 4) carry out deep reflection: the question "why did what happened happen?" emerges. The information is synthesized and analyzed, in addition to a critical interpretation of the process, and 5) Formulate conclusions and communicate new learning.

\section{Results}

\subsection{Sport interests' centers and their orientation towards essential learning for better living}

\author{
"When I am angry, I come, I work and I spend the whole day relaxed" \\ Student DEI Simon Rodriguez
}

The sport Interest Center SIC's aim was to develop ways of essential learning for better living, as sports done in different classes were integrated with other areas, cross cutting themes in the school were proposed to establish a comprehensive education. This is essential, due to the fact that, in accordance with the guidelines of the area, "Physical education training, Recreation and sports can only be considered training when it contributes to the holistic development of children and young people" [1]. The teachers interviewed stated that their practices "not only consisted of teaching them a sport" but "of respecting each other [...] and improving our integral education" and a reflection "on the transformation of the student's life" as well. This was a position with which parents agreed by saying "we believe that it is good, because it helps us to be better in mind and body". This wholeness is realized in two dimensions: individual and social which take shape in a few developments that allow the students greater awareness of themselves and of others. This position is consistent with Dacica's approach, which argues that sport and physical education represent components of a global education, taking into account that its content influences the health, growth and development of children; their developmental movement, psychological and socialization processes ([1], p.1243)

Teachers and students highlight aspects such as self- control, safety, emotional expression, and autonomy as characteristics of the individual dimension in their "being", when referring to specific themes in their development, like punctuality, serenity, discipline, autonomy, and self-esteem. These "values", "[...] begin to generate a new culture" that "very certainly, will lead us to great things, as people and sportsmen". As Carreiro said, "the purpose of physical education, recreation and sport is to prepare children and youth for participation, rewarding the culture of movement through life" ([15], p.27). With regards to "living together", the SICs highlight the social interaction displayed and manifested in coexistence and social skills such as empathy, peer respect and social responsibility.

In addition to the aforementioned, there is a series of references that teachers and students make regarding respect, solidarity and commitment. This view of the SIC "allows participants to learn how to respect and value themselves and others, so that, it is indispensable to the variety and experience of the different activities in the game, leisure, recreation and sport to be implemented continuously", setting the scene for the purposes of 
Physical education at the national level, which is "to support the formation of civil culture and fundamental values for coexistence and peace" [25]. In short, it focuses on the transformation of reality itself, becoming visible in "the language we now use", and the "reduction in the rates of violence at school and in their neighborhoods". Thanks to the opportunity provided by the schools to prevent children from "loitering in the street", they live, on the contrary satisfying bodying experiences that strengthen "the notions of sense, meaning and significance that are so essential to the dynamic human relationship." ([14], p. 177). If we consider what proposes "the relationship with the world is fundamental bodily, because the body is the external element that first makes contact with the world and the human is positioned inside of it, then the pedagogical practice in P.E will be based on an inquiry of the body's ability to relate to others and to the world."

\subsection{Transformative citizenships}

"Our dream is for a transformative citizenship in its context, an active citizenship that thinks about where we came from and where we are going" SIC Karate Teacher DEI La Estancia San Isidro.

Citizenship is understood as the condition from which people participate in defining their destiny as individuals and as a society [25]. To do this, the subject must understand that it is part of a context (family, village, society) in which the forms of interaction and communication of those who make it up are mediated by values, customs, traditions, and standards supported by their members. In the SIC, teachers and students refer to the live-in space as a secure welcoming, inclusive environment, that promotes the development of students "into positive leaders". For the DSE, the SIC constitutes learning environments, where students from dynamic pedagogical processes explore and play collectively established roles and generate systems of knowledge that facilitate their practical experience, these environments allow the student to exercise and develop citizenship, beyond a civil status by belonging to a geographical site, because, as claimed by Herrera, “ citizenship refers to the exercising of multiple skills in the context of the practiced democracy that is dynamic and creative" [21].

In this sense, the SIC will promote the development of skills, attitudes, motivations and practices, essential skills proposed by the District Secretariat of Education in the Comprehensive Plans for Citizenship and Coexistence: Identity, dignity, and rights, duties and respect for the rights of others, sensitivity and emotional management, a sense of life in the body and nature, and participation and coexistence.

\subsection{Building territory}

"My mother is very proud, she came to see me compete and she likes what I do" SIC Karate student. DEI la Estancia San Isidro.

According to the DES, "we are the territory that we inhabit, that is to say, the ways of being, understanding, living, feeling and sharing meaning, in a space that we specify, and makes us belong to something" [1]. According to this approach, the SIC allowed the processes of appropriation of spaces in the areas of school, family and community. This experience "opened up and allowed a greater number of participants in all educational cycles of all the districts of Bogotá. This caused in some cases, the free-time projects to adjust their work to the Institutional Educational Project, where each teacher articulated their proposal, not only related to the sport, but also to the proposal of the IEP to the school. 
Given the dynamics of these conditions, the general community had the necessary tools for its development, with the necessary administrative support.

Regarding the role of the family, the DES gives relevance and meaning to the SIC in two ways: one in which parents approve their child's participation, and the other through participation and support. In summary, the SIC enriches environments using sports, allowing participants to have meaningful experiences that are open to the school environment, family and social fabric, in order to: "transform the collective imagination that has been rotated around the town, (...) to demystify violence, violent actors, transformers of lives" (DEI la Estancia San Isidro), as mentioned by a teacher of a Sport Center.

\subsection{Didactics}

Understanding the SIC as enriched learning environments ([1], p. 30), teachers and students gave account of its development as a meaningful experience thanks to certain features in the sphere of the didactics. Didactics is understood as the theory of teaching: "our discipline is an inherited teaching theory, and indebted to many other disciplines, its destination. However, when dealing with education, it should be constituted, reciprocally in the offering of theoretical analysis in the social field, and of knowledge". Thus, we are able to observe the teaching of harmonization, understood as the process of articulation of the SIC with the dynamics and purposes of the DEI. Consequently, we performed a work set which prompted the exchange of knowledge and communication between the different areas and teachers of the school.

In relation to the specific Didactics of the discipline, it was found that, although the objective of the performance engine is not abandoned, there are spaces in each session to dialogue, share knowledge, set goals, design joint strategies and assess performance. All of this is done "on a needs basis keeping in mind the potential and interests of those affected" [1]. This generates other dynamic interest that promotes learning environments as significant. Decisions about teaching are based on the interests, tastes, needs, motivations, and dispositions of students. Thus, they spoke of practices based on approaches to critical and participatory thinking that highlight all their skills to the school. From this basic practice comes the response to how to teach the teachers, whose main features were: going from the easy to the complex, relying on the example, making use of the inter-learning, promoting self-learning, the enjoyment, the self-control and motivation for achievement, in a scenario of "courtesy, integrity, perseverance, self-control and an indomitable spirit". At this point, the role of the teacher was determinate, being the leader of the educational process and the dynamics that they are currently experiencing, directing them under the above principles and agreements established collectively as the dialogue. Good treatment, the capacity for listening, the demand, and the respect for the rhythms of learning and, especially, its reflexive capability: "as a lesson as one which always needs correcting and improving. I'm making a journal of this work of writing that I'm failing [...], one begins to raise expectations in the sense of leaving training and going forward because it is not there as the training of one is a challenge so improvements must be made to be able to offer students something better."

\subsection{Reflective bodily practices.}

"Doing many things halfway balances my body" SIC Cheerleading student DEI Porvenir

It is observed that the bodily practices have favored the autonomous work and the cooperative tasks as a form of organization in the activities, and that such possibilities have allowed the development of the learning of life essentials, promoting the transformation of 
the interactions of the participants with themselves and with others, as interpreted in "the desire of students to be discovered". Reviewing the expressions of the participants tells of the way in which the proposed actions allowed the interweaving of cooperative work, understood as "that activity undertaken equally and proportionally by two or more persons jointly to achieve the objectives and, ultimately, learn." [20].

The SIC helped to establish new relations among students, improve their attitude toward the group, and improve the relationships based on trust. The bodily practices and experiences allowed body recognition in children and young people from the participating Schools, facilitating multidimensional experiences, that is to say, that only through the corporeal nature, the subject accesses the world of the senses, motor, social, emotional, intellectual, cultural, that, in this case, is achieved by the transfer of the "physical body to the symbolic body" [27], a conscious and thinking body that "is primarily a tool of meaning and symbolization key -a corpus- that is expressed and communicated in society in the form of corporeity" [16] to LIVE TOGETHER, because, as Martin Barbero [22] says "there is no life experience or access to knowledge of the self or of others, which is extracorporal".

\section{Discussion}

Attending the phenomenological approaches stated by Merleau Ponty [24] who argues that corporeality, as bodily experience (embodied), involves emotional, social and symbolic dimensions, it is understood that in the SIC we worked intentionally in favor of the construction of learning about "being" and "coexistence", which are the proposals from the Secretariat of education of Bogotá for the implementation of such strategies.

Merleau Ponty, as opposed to the mechanical dual vision of Descartes, posits that where the mind and the spirit are understood as separate from the body (res cogitans and rest extensa), in which he expresses a total denial of the validity of the senses; proposes "being all one", i.e., that man is the indissoluble union between body and soul, inside and out, because, as he says in his book, humans "don't have a body, they are a body" [23].

The SICs have faced the reigning and dichotomous model from the traditional schooling, according to which the human body and movement are a hindrance to "important" "intellectual" learning, because, among others, they are measured based on national and international standardized tests. Proof of this is the specific weight that every area of the curriculum at the school has. These significant experiences made corporeal experiences that involved students (alumnus: those who are breastfeeding - feed - and grow) in its entirety: "a human being who feels, thinks and does things in relationship with each other and with the world that surrounds him, and from those relationships he builds a world of meanings that give meaning to his life".

From the perspective of Merleau Ponty, according to each ego (what I think of myself) is only achieved when sharing with others, what has been done in the SICs is to combine the expression of their own to be subjective as an intentional act and self-conscious (its sameness), with the act of expressing an idea of corporeal form to the other (otherness). It is to say that, as proposed by Sergio is an intentional staging that "is a concrete form of relationship of the human being with himself, with others and with the world through its corporeality," because, in the end "humans' acts are performed in and to the world" [24].

For the DSE, that sense of "world" construction is not anything other than the construction of the "territory". If "Petting, smelling a flower or play [...] are not the effect of a cause called world, but a dialectical and unfathomable relationship in its entirety between who I am and my environment", the dynamics in the SIC's objective of this study comes to enrich this relationship, thanks to the generation of a new conceptual net crossed by the body, in the Merleaupontian combination of incarnate awareness and conscious 
body, and the abandonment of the claim body-machine or body-gadget process in which, the elaboration of an own corporeality is made, necessarily, recognizing the others corporeality in the play of inter subjectivity, its spaces, times and actions.

In short, the SICs, value the body in relation to other bodies (self-aware and respectful of others) "as a point of reference through which the world is articulated, where come into play throughout the constellation of subjective and intersubjective relations of human beings in society" [19].

It is worth combining careful observation with this type of strategy in the classroom. Taking from its analysis, those lessons that may well guide the work of the classroom, in a country that urgently requires to the rebuilding of the social tissue with strong social and emotional threads, mediated by the body.

\section{References}

1. Secretaría de Educación del Distrito. "Reorganización curricular por ciclos.Acompañamiento Pedagógico 5", Bogotá: Alcaldía Mayor de Bogotá, 205, (2015)

2. C. M. Castañeda, Competencia socio-afectiva en el marco escolar colombiano". Bogotá: Escenarios, 12 (2), Jul., 19-34, (2014)

3. J. Ciarrochi, J.Forgas, J. Mayer, Emotional Intelligence in Everyday Life: a Scientific Inquiry. New York: Psychology Press. 251-260, (2006)

4. Solano, R., Alpargatero. L. Orientaciones para el área de Educación para la Ciudadanía y la Convivencia. Bogotá: Secretaría de Educación, 20-38, (2014)

5. P. Enciso, Estado del Arte de la etno-educación en Colombia con énfasis en política pública. Bogotá: Ministerio de Educación Nacional, (2004)

6. J. Castro, Pedagogía de la Corporeidad y Potencia Humano. Medellín: Educación Física y Deporte, 8(17), 23, (2004)

7. Alcaldía Mayor de Bogotá. Plan de Desarrollo 2012 - 2016 Bogotá Humana, (2012) http://www.canalcapital.gov.co/images/planeacion_pdf/Plan-de-Desarrollo-20122016.pdf

8. Secretaría de Educación de Bogotá. Currículo para la excelencia académica y la $\begin{array}{llllll}\text { formación } & \text { integral } & 40 & \mathrm{x} & 40 . & \text { (2012) }\end{array}$ https://issuu.com/secretariadeeducacionbogota/docs/0_pantalla

9. Secretaría de Educación de Bogotá. "Orientaciones curriculares para el área de Educación Física, Recreación y Deporte". Bogotá: SED, (2014)

10. O. Jara, Sistematización de experiencias, investigación y Evaluación: Aproximaciones desde tres ángulos. Educational Research Global, 1, 156-70, (2004)

11. A. Ghiso, Sistematización: Un pensar el hacer, que se resiste a perder su autonomía. Decisio, 28, 3-8., (2011)

12. M. Barnechea, M. Tirado, La sistematización de experiencias: producción de conocimientos desde y para la práctica. Tendencias y Retos N 15, 97-107, (2010)

13. R. Ávila, La producción de conocimiento en la investigación acción pedagógica (IAPE): Balance de una experimentación. Revista Educação e Pesquisa, 31(3), 503$519,(2005)$

14. A. Almonacid, La educación física como espacio de transformación social y Educativa: perspectivas desde los imaginarios sociales y la ciencia de la motricidad humana. Estudios Pedagógicos 38(1), 177-190., (2012)

15. F. Carreiro, La gestión del currículo a través de competencias: un enfoque desde el contexto portugués». Tándem. Didáctica de la Educación Física, 29, 27., (2009)

16. L. Cencillo, J. García, Antropología y cultura. Guadiana (1973) 
17. L. Dacica, The formative role of physical education and sports. Presentation at: The 6th International Conference Edu World 2014 "Education Facing Contemporary World Issues", (2014). http://ac.els-cdn.com/S187704281501602X/1-s2.0S187704281501602X-main.pdf?_tid=e73fa562-5026-11e5-859f 0000aab0f01\&amp;acdnat $=1441056552 \_0$ e598fc42716ef12102f533360a0818d.

18. J. Fernández, La importancia de la Educación Física en la escuela. Digital Magazine EFDEPORTES.COM, 13 · (130), (2009). http://www.efdeportes.com/efd130/laimportancia- de-la-educacion-fisica- en-la- escuela.htm

19. C. Godina, La teoría de género desde la perspectiva fenomenológica del cuerpo vivido. La Lámpara de Diógenes Magazine. 6, 203-209., (2001)

20. Gutiérrez Del Mora, M. El Trabajo Cooperativo, su diseño y su evaluación. Dificultades y Propuestas. (2009). In conference: Univest 09. http://dugidoc.udg.edu/bitstream/handle/10256/1956/217.pdf?sequence=1.

21. J. Herrera, R., Rodríguez, Citado en Secretaría de Educación. Educación para la ciudadanía y la convivencia. Módulo 2: Ciudad, sociedad y territorio. CINEP, 68., (2014).

22. J. Martín Barbero, De los medios a las mediaciones. Gustavo Gili., (1987)

23. Merleau-Ponty, M. Sens Et Non-Sens. Gallimard., (1966)

24. M. Merleau Ponty, Fenomenología de la percepción. Translation: Jem Cabanes(1993).Translation by Ediciones Península ${ }^{\circledR}$, Proyectos Editoriales y Audiovisuales CBS, S.A., (1945)

25. Ministerio de Educación Nacional. Documento No 15: Orientaciones Pedagógicas para la Educación Física, Recreación y Deporte. MEN, Viceministerio de Educación Preescolar, Básica y Media. Bogotá, 1, 14., (2010)

26. Ministerio de Educación Nacional. Programa de Educación para la Sexualidad y Construcción de Ciudadanía. (2008). http://www.mineducacion.gov.co/1621/article173877.html

27. Morera de Guijarro, J. Problemática del yo en Maine de Biran. Logos. Anales del Seminario de Metafísica, 22, Universidad Complutense de Madrid, pp. 185- 198., (1988). http://revistas.ucm.es/fsl/15756866/articulos/ASEM8788110185A.PDF

28. Secretaría de Educación. Lineamiento Pedagógico Educación para la Ciudadanía y la Convivencia.

http://www.redacademica.edu.co/archivos/redacademica/proyectos/pecc/centro_docum entacion/caja_de_herramientas/serie_1_orientaciones/02_lineamiento_pedagogico_edu cacion_para_la_ciudadania_y_la_convivencia.pdf

29. Secretaría de Educación De Bogotá. Educación para la ciudadanía y la convivencia. Módulo 2: Ciudadanía, sociedad y territorio. CINEP. Bogotá: 2014.

30. A. Sicilia, Educación Física y transformación social: implicaciones desde una epistemología posmoderna. Estudios Pedagógicos, 38, 47-65 (2012)

31. Y. Silveira, Miedo a equivocarse en educación física y deporte. Universidad Miguel Hernández De Elche, Departamento De Psicología de la Salud. 15-32 (2013) 